Published in final edited form as:

Semin Oncol. 2013 December ; 40(6): . doi:10.1053/j.seminoncol.2013.09.013.

\title{
Therapy-related myelodysplasia and acute myeloid leukemia
}

\author{
Smita Bhatia, MD, MPH [Professor and Chair] \\ Department of Population Sciences Ruth Ziegler Chair in Population Research City of Hope \\ Comprehensive Cancer Center Duarte, CA
}

\begin{abstract}
Therapy-related leukemia (t-MDS/AML) is a well known complication of conventional chemoradiotherapy used to treat a variety of primary malignancies including Hodgkin lymphoma (HL) and non-Hodgkin lymphoma (NHL), acute lymphoblastic leukemia (ALL), sarcoma, and ovarian and testicular cancer. The median time to development of t-MDS/AML is 3 to 5 years, with the risk decreasing markedly after the first decade. t-MDS/AML is the major cause of nonrelapse mortality after autologous hematopoietic cell transplantation (HCT) for HL or NHL. The magnitude of risk of t-MDS/AML is higher, and the latency is shorter after HCT, compared to conventional therapy. Two types of t-MDS/AML are recognized depending on the causative therapeutic exposure: an alkylating agent/radiation-related type and a topoisomerase II inhibitorrelated type. Interindividual variability in the risk for development of t-MDS/AML suggests a role for genetic variation in susceptibility to genotoxic exposures. Treatment of t-MDS/AML with conventional therapy is associated with a uniformly poor prognosis, with a median survival of 6 months. Because of the poor response to conventional chemotherapy, allogeneic HCT is recommended. Current research is focused on developing risk prediction and risk reduction strategies.
\end{abstract}

\section{Epidemiology}

Therapy-related leukemia (myelodysplasia and acute myeloid leukemia - t-MDS/AML) is a well known complication of conventional chemoradiotherapy for Hodgkin lymphoma (HL) and non-Hodgkin lymphoma (NHL), ${ }^{1-3}$ acute lymphoblastic leukemia (ALL), sarcoma, and ovarian and testicular cancer. ${ }^{4-9}$ The incidence of t-MDS/AML following conventional therapy ranges from $0.8 \%$ to $6.3 \%$ at 20 years. The median time to development of t-MDS/ AML is 3 to 5 years, with the risk decreasing markedly after the first decade. t-MDS/AML is the major cause of non-relapse mortality after autologous hematopoietic cell transplantation (HCT $)^{10-19}$ for HL or NHL. The incidence of t-MDS/AML ranges from $1.1 \%$ to $24.3 \%$ at 5 years after autologous HCT. The median time to development of t-MDS/ AML is 12 to 24 months after HCT. The magnitude of risk of t-MDS/AML is higher, and the latency is shorter after HCT, compared to conventional therapy.

Factors associated with an increased risk of t-MDS/AML include exposure to alkylating agents, topoisomerase II inhibitors, and radiation therapy, ${ }^{12,19-23}$ and older age at treatment. ${ }^{10,16}$ Among autologous HCT recipients, method of stem cell mobilization (use of

\footnotetext{
(c) 2013 Elsevier Inc. All rights reserved.

Smita Bhatia, MD, MPH, City of Hope National Medical Center, 1500 E. Duarte Road (MOB-4), Duarte CA 91010; Phone (626) 301-8426, Fax (626) 301-8978, sbhatia@coh.org.

Publisher's Disclaimer: This is a PDF file of an unedited manuscript that has been accepted for publication. As a service to our customers we are providing this early version of the manuscript. The manuscript will undergo copyediting, typesetting, and review of the resulting proof before it is published in its final citable form. Please note that during the production process errors may be discovered which could affect the content, and all legal disclaimers that apply to the journal pertain.
} 
peripheral blood stem cells and priming with etoposide for stem cell mobilization) ${ }^{10,12}$ and transplantation conditioning with $\mathrm{TBI}^{22}$ are associated with an increased risk of t-MDS/ AML.

Two types of t-MDS/AML are recognized in the World Health Organization classification depending on the causative therapeutic exposure: an alkylating agent/radiation-related type and a topoisomerase II inhibitor-related type. ${ }^{24}$ Alkylating agent-related t-MDS/AML usually appears 4 to 7 years after exposure to the mutagenic agent. Approximately twothirds of patients present with MDS and the remainder with AML with myelodysplastic features. ${ }^{25,26}$ Patients frequently present with cytopenias. Multilineage dysplasia is often present. There is a high incidence of abnormalities involving chromosomes $5(-5 / \mathrm{del}(5 q))$ and $7(-7 / \mathrm{del}(7 \mathrm{q}))$. In contrast to alkylating agent-related t-MDS/AML, AML secondary to topoisomerase II inhibitors often does not have a preceding myelodysplastic phase, and presents as overt acute leukemia, often with a prominent monocytic component. ${ }^{27,28}$ The latency period between the initiation of treatment with topoisomerase II inhibitors and the onset of leukemia is brief, with a median of 2 to 3 years. ${ }^{28}$ Typically, the t-AML arising in such situations is associated with balanced translocations involving chromosome bands $11 \mathrm{q} 23$ or $21 \mathrm{q} 22 .{ }^{28}$

\section{Genetic susceptibility}

Literature clearly supports the role of chemotherapy and radiation in the development of tMDS/AML ${ }^{29}$ but interindividual variability suggests a role for genetic variation in susceptibility to these genotoxic exposures. The risk of t-MDS/AML could potentially be modified by mutations in high-penetrance genes that lead to serious genetic diseases e.g., LiFraumeni syndrome, ${ }^{30}$ and Fanconi anemia. ${ }^{31-34}$ However, the attributable risk is expected to be very small because of their extremely low prevalence. The interindividual variability in risk of t-MDS/AML is more likely related to common polymorphisms in low-penetrance genes that are responsible for drug metabolism, transport and DNA repair. Genetic variation contributes $20 \%$ to $95 \%$ of the variability in cytotoxic drug disposition. ${ }^{35}$ Polymorphisms in genes involved in drug metabolism and transport are relevant in determining disease-free survival and drug toxicity. ${ }^{36}$ Variation in DNA repair plays a role in susceptibility to de novo cancer, ${ }^{37-41}$ and likely modifies t-MDS/AML risk after exposure to DNA-damaging agents, such as radiation. Interaction of therapeutic exposures with underlying genetic characteristics that alter drug metabolism, transport or DNA repair may be associated with an increased risk of $t-M D S / A M L$.

\section{Drug Metabolism}

Metabolism of genotoxic agents occurs in two phases. Phase I involves activation of substrates into highly reactive electrophilic intermediates that can damage DNA - a reaction principally performed by the cytochrome p450 (CYP) family of enzymes. Phase II enzymes (conjugation) function to inactivate genotoxic substrates. The phase II proteins comprise the glutathione S-transferase (GST), and NAD(P)H:quinone oxidoreductase-1 (NQO1). The balance between the two sets of enzymes is critical to the cellular response to xenobiotics; e.g., high activity of phase I enzyme and low activity of a phase II enzyme can result in DNA damage from the excess of harmful substrates. The xenobiotic substrates of CYP proteins include cyclophosphamide, ifosfamide, thiotepa, doxorubicin, and dacarbazine. ${ }^{42}$ The CYPs transfer singlet oxygen onto their substrates creating highly reactive intermediates which, unless detoxified by phase II enzymes, have a strong ability to damage DNA. ${ }^{43}$ The expression of these enzymes is highly variable among individuals because of several functionally relevant genetic polymorphisms. GSTs detoxify reactive electrophiles via conjugation to reduced glutathione, preventing damage to DNA. Polymorphisms exist in cytosolic subfamilies: $\mu[\mathrm{M}], \pi[\mathrm{P}), \theta[\mathrm{T}]$, and others. GSTs detoxify doxorubicin, lomustine, 
busulfan, chlorambucil, cisplatin, cyclophosphamide, melphalan, etc. ${ }^{44}$ Quinone oxidoreductase NQO1 uses the cofactors NADH and NADPH to catalyze the electron reduction of its substrates, produces less reactive hydroquinones, and therefore prevents generation of reactive oxygen species and free radicals which may subsequently lead to oxidative damage of cellular components. Individuals with at least one GSTP1 codon 105 $\mathrm{Val}$ allele were shown to be significantly over-represented in t-MDS/AML cases compared with de novo $\mathrm{AML}$ cases $(\mathrm{OR}=1.8,95 \% \mathrm{CI}, 1.1-2.9)$. Also, relative to de novo AML, the GSTP1 codon 105 allele occurred more often among t-MDS/AML patients with prior exposure to chemotherapy $(\mathrm{OR}=2.7,95 \% \mathrm{CI}, 1.4-5.1)$, particularly among those with prior exposure to known GSTP1 substrates (OR=4.3, 95\%CI, 1.4-13.2) and not among t-MDS/ AML patients with exposure to radiation alone. ${ }^{45}$ An $N Q O 1$ polymorphism has been shown to be significantly associated with the risk of t-MDS/AML. ${ }^{46}$ In addition, individuals with the CYP3A4- $W$ genotype may be at increased risk of t-MDS/AML, by increasing the production of reactive intermediates that might damage DNA. ${ }^{47}$ A polymorphism profile consisting of $C Y P 1 A 1 * 2 A, \operatorname{del}(G S T T 1)$, and $N Q O 1 * 2$ has been shown to modify the risk of $\mathrm{t}$-AML/MDS. Absence of all three polymorphisms decreased the risk of t-AML/MDS; on the other hand, enhanced risk of t-AML/MDS was seen in the presence of only $N Q O 1 * 2$ or all three polymorphisms. ${ }^{48}$

\section{Drug transport}

P-glycoprotein (encoded by MDR1) traps hydrophobic drugs in the plasma membrane of cells and effluxes them using an ATP-dependent process; many chemotherapeutic drugs are substrates of this protein. A number of polymorphisms exist in the MDRI gene, some proposed to be functional and evaluated as risk factors for t-MDS/AML. ${ }^{49}$

\section{DNA repair}

DNA repair mechanisms protect somatic cells from mutations in tumor suppressor genes and oncogenes that can lead to cancer initiation and progression. An individual's DNA repair capacity appears to be genetically determined. ${ }^{50}$ A number of DNA repair genes contain polymorphic variants, resulting in large inter-individual variations in DNA repair capacity. ${ }^{50}$ Even subtle differences in an individual's DNA repair capacity may be important in the presence of high-intensity genotoxic insults, such as chemotherapy or radiotherapy. Individuals with altered DNA repair mechanisms are likely susceptible to the development of genetic instability that drives the process of carcinogenesis. Over 80 DNA repair genes have been screened and demonstrate evidence of extensive polymorphic variation. ${ }^{50}$

The major repair pathways include mismatch repair, base excision repair, nucleotide excision repair, and DNA double-strand break repair and are described here, along with examples for studies addressing their involvement in the development of t-MDS/AML.

Mismatch repair (MMR) functions to correct mismatched DNA base pairs that arise as a result of misincorporation errors that have avoided polymerase proofreading during DNA replication. ${ }^{51}$ Defects in the MMR pathway result in genetic instability or a mutator phenotype, manifested by an elevated rate of spontaneous mutations characterized as multiple replication errors in simple repetitive DNA sequences (microsatellites) functionally identified as microsatellite instability (MSI). Approximately 50\% of t-MDS/ AML patients have MSI, associated with methylation of the MMR family member MLH1 ${ }^{52,53}$, low expression of MSH2 ${ }^{54}$, or polymorphisms in MSH2 ${ }^{55-58}$. The appearance of MMR-deficient, drug-resistant clones during genotoxic treatment for a primary cancer could be a vital factor in t-MDS/AML susceptibility, particularly because the mutator phenotype would be expected to accelerate the accumulation of further mutations and 
eventually SMN initiation. In addition, loss of MMR may result in deregulation of homologous recombination repair and consequent chromosomal instability. ${ }^{59}$

Double-Strand Breaks (DSBs) in DNA may lead to loss of genetic material, resulting in chromosomal aberrations. High levels of DSBs arise following ionizing radiation and chemotherapy exposures. Cellular pathways available to repair DSBs include homologous recombination (HR), non-homologous end-joining (NHEJ), and single-strand annealing. ${ }^{60}$ HR uses the second, intact copy of the chromosome as a template to copy the information lost at the DSB site on the damaged chromosome - a high-fidelity process. RAD51 is one of the central proteins in the HR pathway, functioning to bind to DNA and promote ATPdependent homologous pairing and strand transfer reactions. ${ }^{61,62}$ RAD51-G-135C polymorphism is significantly over-represented in patients with t-MDS/AML compared with controls (C allele: $\mathrm{OR}=2.7) .{ }^{63} \mathrm{XRCC} 3$ also functions in the HR DSB repair pathway by directly interacting with, and stabilizing RAD51. ${ }^{64} \mathrm{XRCC} 3$, a paralog of RAD51, is also essential for genetic stability. ${ }^{65,66}$ A polymorphism at codon 241 in the $X R C C 3$ gene results in a Thr $\rightarrow$ Met amino acid substitution. ${ }^{67}$ The variant XRCC3-241Met allele has been associated with a higher level of DNA adducts compared with cells with the wild type allele, implying aberrant repair ${ }^{68}$ and has also been associated with increased levels of chromosome deletions in lymphocytes after exposure to radiation. ${ }^{69}$ Although XRCC3Thr241Met was not associated with t-MDS/AML (OR=1.4, 95\%CI, 0.7-2.9), a synergistic effect resulting in an 8-fold increased risk of t-MDS/AML was observed in the presence of $X R C C 3-241 M e t$ and RAD51-135C allele in patients with t-MDS/AML compared with controls. ${ }^{63}$ NHEJ pathway joins broken DNA ends containing very little homology. This process is not always precise and can result in small regions of non-template nucleotides around the site of the DNA break, potentially relevant in MLL-translocation associated with t-MDS/AML.

Base Excision Repair (BER) pathway corrects individually damaged bases occurring as a result of ionizing radiation and exogenous xenobiotic exposure. The XRCC1 protein plays a central role in the BER pathway and also in the repair of single strand breaks, by acting as a scaffold and recruiting other DNA repair proteins. ${ }^{70,71}$ The protein also has a BRCA1 Cterminus (BRCT) domain - a characteristic of proteins involved in DNA damage recognition and response. The presence of variant XRCC1-399Gln has been shown to be protective for t-MDS/AML. ${ }^{72}$

Nucleotide Excision Repair (NER) removes structurally unrelated bulky damage induced by radiation and chemotherapy. The NER pathway is linked to transcription, and components of the pathway comprise the basal transcription factor IIH complex (TFIIH), which is required for transcription initiation by RNA polymerase II. One of the genes involved in the NER pathway (ERCC2) is a member of the TFIIH complex. The polymorphic Gln variant (ERCC2 Lys $751 G \ln$ ) is associated with t-MDS/AML. ${ }^{73}$

\section{Pathogenesis}

t-MDS/AML is a clonal hematologic disorder that is the consequence of an acquired somatic mutation induced by cytotoxic therapy in hematopoietic stem and progenitor cells, which confers a proliferative and/or survival advantage. t-MDS/AML after autologous HCT appears to result from genetic damage to the stem and/or progenitor cell from cytotoxic treatment, which may be potentiated by the transplant process itself through several mechanisms, including hematopoietic cell mobilization, collection, and storage, myeloablative chemotherapy and radiation, and the stress of engraftment and hematopoietic regeneration on the hematopoietic precursors. ${ }^{13,74,75}$ Alkylating agents kill cancer cells by transferring alkyl groups to cellular molecules. Alkylation results in inaccurate base pairing 
during replication and single- and double-strand breaks in the double helix as the alkylated bases are repaired. ${ }^{76}$ Topoisomerase II inhibitors stabilize the enzyme-DNA covalent intermediate, decrease the re-ligation rate, and cause chromosomal breakage. ${ }^{47,77}$ Repair of chromosomal damage results in chromosomal translocations, leading to leukemogenesis. ${ }^{47,78,79}$ Most of the translocations disrupt a breakpoint cluster region between exons 5 and 11 of the band 11q23 and fuse mixed lineage leukemia $(M L L)$ with a partner gene. ${ }^{80-82}$ Translocations to $11 \mathrm{q} 23$ predominate following exposure to epipodophyllotoxins, whereas translocations to $21 \mathrm{q} 22$, inv(16), $t(15,17)$, and $\mathrm{t}(9,22)$ most often occur following anthracyclines. ${ }^{83}$

The $p 53$ gene has a critical role in DNA damage response signaling, affecting cell cycle, cell death, and DNA repair pathways. Abnormal $p 53$ activity could lead to reduced ability to repair DNA damage, resulting in genomic instability and increased susceptibility to leukemogenesis. In patients with de novo MDS and AML, p53 mutations are seen in fewer than $10 \%$ of patients. However, p53 mutations have been identified in $27 \%$ to $50 \% 56,84,85$ of the t-MDS/AML patients. These mutations are nongermline, restricted to the leukemic cells, and are more common after exposure to alkylating agents, with t-MDS/AML characterized by chromosome 5 and/or 7 losses. Ellis et al examined the association between t-MDS/AML and 2 common functional p53-pathway variants - the MDM2 SNP309 and the TP53 codon 72 polymorphism. ${ }^{86}$ Neither polymorphism demonstrated a significant association. However, an interactive effect was detected such that MDM2 TT TP53 Arg/Arg double homozygotes, and individuals carrying both a MDM2 G allele and a TP53 Pro allele were at increased risk of chemotherapy-related t-MDS/AML. TP53 modulates DNA repair and apoptosis upon DNA damage. A common germline polymorphism of TP53, P72R, produces a Proline to Arginine change that enhances apoptotic activity 15-fold. Ding et al demonstrated a significant interaction between P72R and C677T, a coding SNP in MTHFR. The homozygous T allele of C677T conferred and increased risk ( $\mathrm{p}<0.001)$ when combined with the Pro carrier of P72R (conferring decreased apoptotic activity) compared to its combination with homozygous Arg. ${ }^{87}$

Telomeres are noncoding regions of DNA that provide a cap at the ends of chromosomes and prevent dicentric fusion and other chromosomal aberrations. ${ }^{88}$ Each somatic cell division is associated with a loss of telomere length. Cumulative telomere shortening can impose a limit on cell divisions and lead to cell senescence. Telomere shortening is also associated with genetic instability ${ }^{89}$ In hematopoietic tissues, there is progressive shortening of telomere length through life, with considerable variability between agematched individuals. ${ }^{90}$ Following genotoxic exposure, the increased replicative demand on hematopoietic cells associated with hematopoietic regeneration can lead to accelerated telomere shortening. Telomere shortening could contribute to development of t-MDS/AML by limiting hematopoietic proliferation and regenerative capacity and inducing genetic instability. Telomere length in serial peripheral blood samples from patients with t-MDS/ AML after autologous HCT for lymphoma and matched lymphoma controls showed a sharp decline after day 100, but prior to development of t-MDS/AML. ${ }^{91}$ In contrast, controls showed no significant changes in telomere length after day 100. These findings suggest that t-MDS/AML development is likely preceded by altered telomere dynamics in hematopoietic cells. Accelerated telomere loss in patients developing t-MDS/AML could reflect increased clonal proliferation and/or altered telomere regulation in pre-malignant cells.

\section{Outcome}

Treatment of t-MDS/AML with conventional therapy is associated with a uniformly poor prognosis, with a median survival of 6 months. Because of the poor response to conventional chemotherapy, allogeneic HCT has been attempted. ${ }^{92-101}$ The BU/CY 
conditioning regimen is associated with the best 5-year relapse free survival (43\%) and lowest nonrelapse mortality (28\%). Relapse rates are lower with unrelated donor transplants. Relapse probability and relapse-free survival correlate significantly with disease stage and karyotype. An optimized cytogenetic classification (adverse cytogenetics: abnormal 7 or complex; favorable cytogenetics: $5 \mathrm{q}-$ or $20 \mathrm{q}-$ or $\mathrm{Y}$ - or normal; intermediate: all others) is the strongest prognostic factor for overall survival through its impact on the risk of relapse. ${ }^{99}$ After accounting for cytogenetics, patients with t-MDS/AML have an equivalent outcome to those with de novo disease. ${ }^{100}$ A prediction model of survival after allogeneic HCT for t-MDS/AML has used the following 4 risk factors: i) age older than 35 years; ii) poor-risk cytogenetics; iii) t-AML not in remission or advanced t-MDS; iv) donor other than an HLA-identical sibling or a partially or well-matched unrelated donor. Five-year survival for subjects with none, $1,2,3$, or 4 of these risk factors was $50 \%, 26 \%, 21 \%, 10 \%$, and $4 \%$, respectively. ${ }^{102}$

\section{Risk Prediction and Risk Reduction Strategies}

Because of the poor prognosis associated with t-MDS/AML, identification of early biomarkers would allow the timely use of appropriate measures to treat the disorder, such as reduced intensity conditioning (RIC), rather than waiting for the t-MDS/AML to present in the clinically overt form, when the disease burden would require higher-intensity therapy, with a greater risk of resultant morbidity. Several studies have attempted to correlate identification of genetically abnormal clones with subsequent risk of t-MDS/AML. Abnormal clones are frequently detected on cytogenetic analysis after autologous HCT for lymphoma and $30 \%$ to $50 \%$ of these patients develop overt t-MDS/AML. ${ }^{13,14,21}$ Evaluation by FISH enhances sensitivity of detection of chromosomal abnormalities; significant levels of clonally abnormal cells were detected by FISH prior to high-dose therapy in 20 of 20 patients who developed t-MDS/AML, but only in 3 of 24 patients who did not. ${ }^{103}$ Clonal hematopoiesis at the time of transplant using an X-inactivation-based clonality assay at the human androgen receptor locus (HUMARA), was predictive of the development of t-MDS/ t-AML. ${ }^{15}$ This assay is limited by its low sensitivity, requiring a high proportion of monoclonal cells to be present prior to reaching the threshold for detection, and is applicable only to female patients. Gene expression profile of ALL cells at diagnosis was shown to be predictive of risk of t-MDS/AML. ${ }^{104}$ Altered gene expression (of genes regulating mitochondrial function, metabolism, and hematopoietic regulation) was observed in CD34+ cells from the peripheral blood stem cells (PBSCs) of patients who subsequently developed t-MDS/AML after autologous HCT for lymphoma when compared with controls who did not. ${ }^{105}$ An optimal 38-gene PBSC classifier accurately distinguished patients who did or did not develop t-MDS/AML in an independent group of patients. The development of t-MDS/ AML appears to require the acquisition of more than one mutation. Moreover, t-MDS/AML is a heterogeneous disorder with multiple subtypes characterized by different genetic abnormalities. Therefore, the identification of a single genetic abnormality may not necessarily have predictive value for development of t-MDS/AML.

It is possible to consider potential strategies to reduce the risk of t-MDS/AML, based on our understanding of the risk factors and pathogenesis of t-MDS/AML. Such strategies may include alteration in autologous stem cell procurement regimens to eliminate factors associated with increased risk of this complication. Standardized screening of patients in the immediate pre-HCT period with marrow pathology and cytogenetics could potentially help identify high risk populations that would then benefit from an allogeneic rather than autologous HCT. If strategies to develop predictors for patients at high risk prior to HCT are realized, alternative treatment approaches such as allogeneic transplantation or nontransplant modalities may be worth considering for patients identified being at increased risk of this complication. 


\section{Future Directions}

Studies examining single gene polymorphisms in small heterogeneous samples can result in inconclusive results. Presence of functional redundancy results in a variant in one gene to have minimal consequences, whereas the combination of variants in two or more genes to potentially have more serious consequences resulting in the emergence of a malignant phenotype. Furthermore, there exists a need to systematically examine gene-therapy interactions, because of the absence of detailed therapeutic exposure data collected by the previous studies and the small sample sizes. A systematic assessment of the role of drugmetabolizing enzymes, DNA repair genes and drug transport in the development of t-MDS/ AML is currently under way in a Children's Oncology Group-wide study, funded by the National Cancer Institute.

\section{References}

1. Travis LB, Curtis RE, Glimelius B, et al. Second cancers among long-term survivors of nonHodgkin's lymphoma. J Natl Cancer Inst. 1993; 85:1932-7. [PubMed: 8230284]

2. Boivin JF, Hutchinson GB, Zauber AG, et al. Incidence of second cancers in patients treated for Hodgkin's disease. J Natl Cancer Inst. 1995; 87:732-41. [PubMed: 7563150]

3. Bhatia S, Robison LL, Oberlin O, et al. Breast cancer and other second neoplasms after childhood Hodgkin's disease. N Engl J Med. 1996; 334:745-51. [PubMed: 8592547]

4. Pui C-H, Ribiero RC, Hancock M, et al. Acute myeloid leukemia in children treated with epipodophyllotoxins for acute lymphoblastic leukemia. N Engl J Med. 1991; 325:1682-7. [PubMed: 1944468]

5. Neglia JP, Meadows AT, Robison LL, et al. Second neoplasms after acute lymphoblastic leukemia in childhood. N Engl J Med. 1991; 325:1330-6. [PubMed: 1922234]

6. Bhatia S, Krailo MD, Chen Z, et al. Therapy-related myelodysplasia and acute myeloid leukemia after Ewing sarcoma and primitive neuroectodermal tumor of bone: A report from the Children's Oncology Group. Blood. 2007; 109:46-51. [PubMed: 16985182]

7. Bhatia S, Sather HN, Pabustan OB, et al. Low incidence of second neoplasms among children diagnosed with acute lymphoblastic leukemia after 1983. Blood. 2002; 99:4257-64. [PubMed: 12036851]

8. Travis LB, Andersson M, Gospodarowicz M, et al. Treatment-associated leukemia following testicular cancer. J Natl Cancer Inst. 2000; 92:1165-71. [PubMed: 10904090]

9. Travis LB, Holowaty EJ, Bergfeldt K, et al. Risk of leukemia after platinum-based chemotherapy for ovarian cancer. N Engl J Med. 1999; 340:351-7. [PubMed: 9929525]

10. Bhatia S, Ramsay K, Steinbuch M, et al. Malignant neoplasms following bone marrow transplantation. Blood. 1996; 87:3633-9. [PubMed: 8611687]

11. Howe R, Micallef IN, Inwards DJ, et al. Secondary myelodysplastic syndrome and acute myelogenous leukemia are significant complications following autologous stem cell transplantation for lymphoma. Bone Marrow Transplant. 2003; 32:317-24. [PubMed: 12858205]

12. Krishnan A, Bhatia S, Slovak ML, et al. Predictors of therapy-related leukemia and myelodysplasia following autologous transplantation for lymphoma: an assessment of risk factors. Blood. 2000; 95:1588-93. [PubMed: 10688812]

13. Stone RM. Myelodysplastic syndrome after autologous transplantation for lymphoma: the price of progress? Blood. 1994; 83:3437-40. [PubMed: 8204870]

14. Traweek ST, Slovak ML, Nademanee P, et al. Clonal karyotypic hematopoietic cell abnormalities occurring after autologous bone marrow transplantation for Hodgkin disease and non-Hodgkin lymphoma. Blood. 1994; 84:957-63. [PubMed: 8043877]

15. Mach-Pascual S, Legare RD, Lu D, et al. Predictive value of clonality assays in patients with nonHodgkin's lymphoma undergoing autologous bone marrow transplant: a single institution study. Blood. 1998; 91:4496-503. [PubMed: 9616144] 
16. Andre M, Henry-Amar M, Blaise D, et al. Treatment-related deaths and second cancer risk after autologous stem cell transplantation for Hodgkin's disease. Blood. 1998; 92:1933-40. [PubMed: 9731050]

17. Laughlin MJ, McGaughey DS, Crews JR, et al. Secondary myelodysplasia and acute leukemia in breast cancer patients after autologous bone marrow transplant. J Clin Oncol. 1998; 16:1008-12. [PubMed: 9508184]

18. Kollmannsberger C, Beyer J, Droz J-P, et al. Secondary leukemia following cumulative doses of etoposide in patients treated for advanced germ cell tumors. J Clin Oncol. 1998; 16:3386-91. [PubMed: 9779717]

19. Govindarajan R, Jagannath S, Flick JT, et al. Preceding standard therapy is the likely cause of MDS after autotransplants for multiple myeloma. Br J Haematol. 1996; 95:349-53. [PubMed: 8904891]

20. Pedersen-Bjergaard J, Pedersen M, Myhre J, et al. High risk of therapy-related leukemia after BEAM chemotherapy and autologous stem cell transplantation for previously treated lymphomas is mainly related to primary chemotherapy and not to BEAM-transplantation procedure. Leukemia. 1997; 11:1654-60. [PubMed: 9324285]

21. Gilliland DG, Gribben JG. Evaluation of the risk of therapy-related MDS/AML after autologous stem cell transplantation. Biol Blood Marrow Transplant. 2002; 8:9-16. [PubMed: 11846355]

22. Milligan DW, Ruiz De, Elvira MC, Kolb H-J, et al. Secondary leukemia and myelodysplasia after autografting for lymphoma: results from the EBMT. Br J Haematol. 1999; 106:1020-6. [PubMed: 10520006]

23. Wheeler C, Khurshid A, Ibrahim J, et al. Incidence of post-transplant myelodysplasia/acute leukemia in non-Hodgkin's lymphoma patients compared with Hodgkin's disease patients undergoing autologous transplantation following cyclophosphamide, carmustine, and etoposide (CBV). Leuk Lymphoma. 2001; 40:499-509. [PubMed: 11426523]

24. Vardiman JW, Harris NL, Brunning RD. The World Health Organization (WHO) classification of the myeloid neoplasms. Blood. 2002; 100:2292-302. [PubMed: 12239137]

25. Le Beau MM, Albain KS, Larson RA, et al. Clinical and cytogenetic correlations in 63 patients with therapy-related myelodysplastic syndromes and acute nonlymphocytic leukemia: further evidence for characteristic abnormalities of chromosomes 5 and 7. J Clin Oncol. 1986; 4:325-45. [PubMed: 3950675]

26. Karp JE, Sarkodee-Adoo CB. Therapy-related acute leukemia. Clin Lab Med. 2000; 20:71-9. [PubMed: 10702897]

27. Pedersen-Bjergaard J, Andersen MK, Christiansen DH, et al. Genetic pathways in therapy-related myelodysplasia and acute myeloid leukemia. Blood. 2002; 99:1909-12. [PubMed: 11877259]

28. Pedersen-Bjergaard J, Philip P. Balanced translocation involving chromosome bands 11q23 and 21 q22 are highly characteristic of myelodysplasia and leukemia following therapy with cytostatic agents targeting at DNA-topoisomerase II. Blood. 1991; 78:1147-8. [PubMed: 1651134]

29. van Leeuwen, FE.; Travis, LB. Cancer: principles and practice of oncology. 7th edition. Lippincott Williams and Wilkins; Philadelphia: 2005. Second Cancers; p. 2575-602.

30. Limacher JM, Frebourg T, Natarajan-Ame S, et al. Two metachronous tumors in the radiotherapy fields of a patient with Li-Fraumeni syndrome. Int J Cancer. 2001; 96:238-42. [PubMed: 11474498]

31. Alter BP. Cancer in Fanconi anemia, 1927-2001. Cancer. 2003; 97:425-40. [PubMed: 12518367]

32. Tischkowitz M, Dokal I. Fanconi anaemia and leukaemia - clinical and molecular aspects. Br J Haematol. 2004; 126:176-91. [PubMed: 15238138]

33. Rosenberg PS, Alter BP, Ebell W. Cancer risks in Fanconi anemia: findings from the German Fanconi Anemia Registry. Haematologica. 2008; 93:511-7. [PubMed: 18322251]

34. Kennedy RD, D'Andrea AD. The Fanconi Anemia/BRCA pathway: new faces in the crowd. Genes Dev. 2005; 19:2925-40. [PubMed: 16357213]

35. Kalow W, Ozdemir V, Tang BK, et al. The science of pharmacological variability: an essay. Clin Pharmacol Ther. 1999; 66:445-7. [PubMed: 10579470]

36. Evans WE, McLeod HL. Pharmacogenomics--drug disposition, drug targets, and side effects. N Engl J Med. 2003; 348:538-49. [PubMed: 12571262] 
37. Berwick M, Vineis P. Markers of DNA repair and susceptibility to cancer in humans: an epidemiologic review. J Natl Cancer Inst. 2000; 92:874-97. [PubMed: 10841823]

38. Goode EL, Ulrich CM, Potter JD. Polymorphisms in DNA repair genes and associations with cancer risk. Cancer Epidemiol Biomarkers Prev. 2002; 11:1513-30. [PubMed: 12496039]

39. Bhatti P, Doody MM, Alexander BH, et al. Breast cancer risk polymorphisms and interaction with ionizing radiation among U.S. radiologic technologists. Cancer Epidemiol Biomarkers Prev. 2008; 17:2007-11. [PubMed: 18708391]

40. Bhatti P, Struewing JP, Alexander BH, et al. Polymorphisms in DNA repair genes, ionizing radiation exposure and risk of breast cancer in U.S Radiologic technologists. Int J Cancer. 2008; 122:177-82. [PubMed: 17764108]

41. Rajaraman P, Bhatti P, Doody MM, et al. Nucleotide excision repair polymorphisms may modify ionizing radiation-related breast cancer risk in US radiologic technologists. Int J Cancer. 2008; 123:2713-6. [PubMed: 18767034]

42. McFadyen MC, Melvin WT, Murray GI. Cytochrome P450 enzymes: novel options for cancer therapeutics. Mol Cancer Ther. 2004; 3:363-71. [PubMed: 15026557]

43. Park JY, Shigenaga MK, Ames BN. Induction of cytochrome P4501A1 by 2,3,7,8tetrachlorodibenzo-p-dioxin or indolo(3,2-b)carbazole is associated with oxidative DNA damage. Proc Natl Acad Sci U S A. 1996; 93:2322-7. [PubMed: 8637871]

44. Hayes JD, Flanagan JU, Jowsey IR. Glutathione transferases. Annu Rev Pharmacol Toxicol. 2005; 45:51-88. [PubMed: 15822171]

45. Allan JM. Polymorphism in glutathione S-transferase P1 is associated with susceptibility to chemotherapy-induced leukemia. Proc Natl Acad Sci U S A. 2001; 98:11592-7. al. e. [PubMed: 11553769]

46. Naoe T, Takeyama K, Yokozawa T, et al. Analysis of genetic polymorphism in NQO1, GST-M1, GST-T1, and CYP3A4 in 469 Japanese patients with therapy-related leukemia/myelodysplastic syndrome and de novo acute myeloid leukemia. Clin Cancer Res. 2000; 6:4091-5. [PubMed: 11051261]

47. Felix CA, Walker AH, Lange BJ, et al. Association of CYP3A4 genotype with treatment-related leukemia. Proc Natl Acad Sci U S A. 1998; 95:13176-81. [PubMed: 9789061]

48. Bolufer P, Collado M, Barragan E, et al. Profile of polymorphisms of drug-metabolising enzymes and the risk of therapy-related leukaemia. Br J Haematol. 2007; 136:590-6. [PubMed: 17367411]

49. Rund D. Therapy-related leukemia: clinical characteristics and analysis of new molecular risk factors in 96 adult patients. Leukemia. 2005; 19:1919-28. al. e. [PubMed: 16167058]

50. Collins A, Harrington V. Repair of oxidative DNA damage: assessing its contribution to cancer prevention. Mutagenesis. 2002; 17:489-93. [PubMed: 12435846]

51. Karran P, Offman J, Bignami M. Human mismatch repair, drug-induced DNA damage, and secondary cancer. Biochimie. 2003; 85:1149-60. [PubMed: 14726020]

52. Casorelli I, Offman J, Mele L, et al. Drug treatment in the development of mismatch repair defective acute leukemia and myelodysplastic syndrome. DNA Repair (Amst). 2003; 2:547-59. [PubMed: 12713812]

53. Seedhouse CH, Das-Gupta EP, Russell NH. Methylation of the hMLH1 promoter and its association with microsatellite instability in acute myeloid leukemia. Leukemia. $2003 ; 17: 83-8$. [PubMed: 12529664]

54. Zhu YM, Das-Gupta EP, Russell NH. Microsatellite instability and p53 mutations are associated with abnormal expression of the MSH2 gene in adult acute leukemia. Blood. 1999; 94:733-40. [PubMed: 10397740]

55. Worrillow LJ, Travis LB, Smith AG, et al. An intron splice acceptor polymorphism in hMSH2 and risk of leukemia after treatment with chemotherapeutic alkylating agents. Clin Cancer Res. 2003; 9:3012-20. [PubMed: 12912950]

56. Horiike S, Misawa S, Kaneko H, et al. Distinct genetic involvement of the TP53 gene in therapyrelated leukemia and myelodysplasia with chromosomal losses of Nos 5 and/or 7 and its possible relationship to replication error phenotype. Leukemia. 1999; 13:1235-42. [PubMed: 10450752]

57. Fishel R, Lescoe MK, Rao MR, et al. The human mutator gene homolog MSH2 and its association with hereditary nonpolyposis colon cancer. Cell. 1993; 75:1027-38. [PubMed: 8252616] 
58. Brentnall TA, Rubin CE, Crispin DA, et al. A germline substitution in the human MSH2 gene is associated with high-grade dysplasia and cancer in ulcerative colitis. Gastroenterology. 1995; 109:151-5. [PubMed: 7797014]

59. Worrillow LJ, Allan JM. Deregulation of homologous recombination DNA repair in alkylating agent-treated stem cell clones: a possible role in the aetiology of chemotherapy-induced leukaemia. Oncogene. 2006; 25:1709-20. [PubMed: 16278672]

60. O'Driscoll M, Jeggo PA. The role of double-strand break repair - insights from human genetics. Nat Rev Genet. 2006; 7:45-54. [PubMed: 16369571]

61. Baumann P, West SC. Role of the human RAD51 protein in homologous recombination and double-stranded-break repair. Trends Biochem Sci. 1998; 23:247-51. [PubMed: 9697414]

62. Jawad M, Seedhouse CH, Russell N, et al. Polymorphisms in human homeobox HLX1 and DNA repair RAD51 genes increase the risk of therapy-related acute myeloid leukemia. Blood. 2006; 108:3916-8. [PubMed: 16902145]

63. Seedhouse C, Faulkner R, Ashraf N, et al. Polymorphisms in genes involved in homologous recombination repair interact to increase the risk of developing acute myeloid leukemia. Clin Cancer Res. 2004; 10:2675-80. [PubMed: 15102670]

64. Bishop DK. Xrcc3 is required for assembly of Rad51 complexes in vivo. J Biol Chem. 1998; 273:21482-8. al. e. [PubMed: 9705276]

65. Tebbs RS. Correction of chromosomal instability and sensitivity to diverse mutagens by a cloned cDNA of the XRCC3 DNA repair gene. Proc Natl Acad Sci U S A. 1995; 92:6354-8. al. e. [PubMed: 7603995]

66. Pierce AJ, Johnson RD, Thompson LH, et al. XRCC3 promotes homology-directed repair of DNA damage in mammalian cells. Genes Dev. 1999; 13:2633-8. [PubMed: 10541549]

67. Shen MR, Jones IM, Mohrenweiser H. Nonconservative amino acid substitution variants exist at polymorphic frequency in DNA repair genes in healthy humans. Cancer Res. 1998; 58:604-8. [PubMed: 9485007]

68. Matullo G. XRCC1, XRCC3, XPD gene polymorphisms, smoking and (32)P-DNA adducts in a sample of healthy subjects. Carcinogenesis. 2001; 22:1437-45. al. e. [PubMed: 11532866]

69. Au WW, Salama SA, Sierra-Torres CH. Functional characterization of polymorphisms in DNA repair genes using cytogenetic challenge assays. Environ Health Perspect. 2003; 111:1843-50. [PubMed: 14630517]

70. Caldecott KW, McKeown CK, Tucker JD, et al. An interaction between the mammalian DNA repair protein XRCC1 and DNA ligase III. Mol Cell Biol. 1994; 14:68-76. [PubMed: 8264637]

71. Kubota Y, Nash RA, Klungland A, et al. Reconstitution of DNA base excision-repair with purified human proteins: interaction between DNA polymerase beta and the XRCC1 protein. EMBO J. 1996; 15:6662-70. [PubMed: 8978692]

72. Seedhouse $\mathrm{C}$. The genotype distribution of the XRCC1 gene indicates a role for base excision repair in the development of therapy-related acute myeloblastic leukemia. Blood. 2002; 100:37616. al. e. [PubMed: 12393447]

73. Allan JM. Genetic variation in XPD predicts treatment outcome and risk of acute myeloid leukemia following chemotherapy. Blood. 2004; 104:3872-7. al. e. [PubMed: 15339847]

74. Pedersen-Bjergaard J, Andersen M, Christiansen DH. Therapy-related acute myeloid leukemia and myelodysplasia after high-dose chemotherapy and autologous stem cell transplantation. Blood. 2000; 95:3273-9. [PubMed: 10828005]

75. Bhatia R, Van Heijzen K, Palmer A, et al. Longitudinal assessment of hematopoietic abnormalities after autologous hematopoietic cell transplantation for lymphoma. J Clin Oncol. 2005; 23:6699_ 711. [PubMed: 16170178]

76. Sanderson BJ, Shield AJ. Mutagenic damage to mammalian cells by therapeutic alkylating agents. Mutat Res. 1996; 355:41-57. [PubMed: 8781576]

77. Corbett AH, Osheroff N. When good enzymes go bad: conversion of topoisomerase II to a cellular toxin by antineoplastic drugs. Chem Res Toxicol. 1993; 6:585-97. [PubMed: 8292734]

78. Lovett B, Strumberg D, Blair I, et al. Etoposide metabolites enhance DNA topoisomerase II cleavage near leukemia-associated MLL translocation breakpoints. Biochemistry. 2001; 40:115970. [PubMed: 11170441] 
79. Megonigal M, Cheung N-K, Rappaport E, et al. Detection of leukemia-associated MLLGAS7 translocation early during chemotherapy with DNA topoisomerase II inhibitors. Proc Natl Acad Sci U S A. 2000; 97:2814-19. [PubMed: 10706619]

80. Felix C, Lange B, Hosler M, et al. Chromosome band 11q23 translocation breakpoints are DNA topoisomerase II cleavage site. Cancer Res. 1995; 55:4287-92. [PubMed: 7671237]

81. Bower M, Parry P, Gibbons B, et al. Human trithorax gene rearrangements in therapy-related acute leukemia after etoposide treatment. Leukemia. 1994; 8:226-9. [PubMed: 8309246]

82. Broeker PLS, Super HG, Thirman MJ, et al. Distribution of 11q23 breakpoints within the MLL breakpoint cluster region in de novo acute leukemia and therapy-related acute myeloid leukemia: correlation with scaffold attachment regions and topoisomerase II consensus binding sites. Blood. 1996; 87:1912-22. [PubMed: 8634439]

83. Andersen MK, Johansson B, Larsen S, et al. Chromosomal abnormalities in secondary MDS and AML: relationship to drugs and radiation with specific emphasis on the balanced rearrangements. Haematologica. 1998; 83:438-8. [PubMed: 9658729]

84. Ben-Yehuda D, Krichevsky S, Caspi O, et al. Microsatellite instability and p53 mutations in therapy-related leukemia suggest mutator phenotype. Blood. 1996; 88:4296-303. [PubMed: 8943866]

85. Christiansen DH, Andersen MK, Pedersen-Bjergaard J. Mutations with loss of heterozygosity of p53 are common in therapy-related myelodysplasia and acute myeloid leukemia after exposure to alkylating agents and significantly associated with deletion or loss of 5q, a complex karyotype, and a poor prognosis. J Clin Oncol. 2001; 19:1405-13. [PubMed: 11230485]

86. Ellis NA. MDM2 SNP309 and TP53 Arg72Pro interact to alter therapy-related acute myeloid leukemia susceptibility. Blood. 2008; 112:741-9. al. e. [PubMed: 18426989]

87. Ding Y, Sun C-L. Genetic susceptibility to therapy-related leukemia after Hodgkin lymphoma or non-Hodgkin lymphoma: role of drug metabolism, apoptosis, and DNA repair. BCJ. 2012; 2:e58. al. e.

88. Blackburn EH. Structure and function of telomeres. Nature. 1991; 266:569-73. [PubMed: 1708110]

89. Hackett JA, Feldser DM, Greider CW. Telomere dysfunction increases mutation rate and genomic instability. Cell. 2001; 106:275-86. [PubMed: 11509177]

90. Vaziri H, Dragowska W, Allsopp RC, et al. Evidence for a mitotic clock in human hematopoietic stem cells: loss of telomeric DNA with age. Proc Natl Acad Sci U S A. 1994; 91:9857-60. [PubMed: 7937905]

91. Chakraborty S, Sun C-L, Francisco L, et al. Accelerated Telomere Shortening in Hematopoietic Cells Preceding Development of therapy-related myelodysplasia or acute myeloid leukemia (tMDS/AML) after Autologous Transplantation for Lymphoma. J Clin Oncol. 2009; 27:791-8. [PubMed: 19124806]

92. Friedberg JW, Neuberg D, Stone R, et al. Outcome of patients with myelodysplastic syndrome after autologous bone marrow transplantation for non- Hodgkin's lymphoma. J Clin Oncol. 1999; 17:3128-35. [PubMed: 10506609]

93. Witherspoon RP, Deeg HJ. Allogeneic bone marrow transplantation for secondary leukemia or myelodysplasia. Haematologica. 1999; 84:1085-7. [PubMed: 10586209]

94. Yakoub-Agha I, de La Salmoniere P, Ribaud P, et al. Allogeneic bone marrow transplantation for therapy-related myelodysplastic syndrome and acute myeloid leukemia: a long-term study of 70 patients. Report of the French society of bone marrow transplantation. J Clin Oncol. 2000; 18:963-71. [PubMed: 10694545]

95. Anderson JE, Gooley TA, Schoch G, et al. Stem cell transplantation for secondary acute myeloid leukemia: evaluation of transplantation as initial therapy or following induction chemotherapy. Blood. 1997; 89:2578-85. [PubMed: 9116305]

96. Appelbaum FR, LeBeau MM, Willman C. Secondary leukemia. Hematology Am Soc Hematol Educ Prog. 1996:33-47.

97. Quesnel B, Kantarjian H, Bjergaard JP, et al. Therapy-related acute myeloid leukemia with $\mathrm{t}(8 ; 21)$, inv(16), and $t(8 ; 16)$ : a report on 25 cases and review of the literature. J Clin Oncol. 1993; 11:2370-9. [PubMed: 8246025] 
98. Witherspoon RP, Deeg HJ, Storer B, et al. Hematopoietic stem-cell transplantation for treatment related leukemia or myelodysplasia. J Clin Oncol. 2001; 19:2134-41. [PubMed: 11304765]

99. Chang MC, Chen TY, Tang JL, et al. Leukapheresis and cranial irradiation in patients with hyperleukocytic acute myeloid leukemia: no impact on early mortality and intracranial hemorrhage. Am J Hematol. 2007; 82:976-80. [PubMed: 17636473]

100. Armand P, Kim HT, DeAngelo DJ, et al. Impact of cytogenetics on outcome of de novo and therapy-related AML and MDS after allogeneic transplantation. Biol Blood Marrow Transplant. 2007; 13:655-64. [PubMed: 17531775]

101. Kroger N, Brand R, van Biezen A, et al. Risk factors for therapy-related myelodysplastic syndrome and acute myeloid leukemia treated with allogeneic stem cell transplantation. Haematologica. 2009; 94:542-9. [PubMed: 19278968]

102. Litzow M, Tarima S, Perez WS, et al. Allogeneic transplantation for therapy-related myelodysplastic syndrome and acute myeloid leukemia. Blood. 2010; 115:1850-7. [PubMed: 20032503]

103. Lillington DM, Micallef IN, Carpenter E, et al. Detection of chromosome abnormalities pre-high dose treatment in patients developing therapy-related myelodysplasia and secondary acute myelogenous leukemia after treatment for non- Hodgkin's lymphoma. J Clin Oncol. 2001; 19:2472-81. [PubMed: 11331326]

104. Yeoh E-J, Ross ME, Shurtleff SA, et al. Classification, subtype discovery, and prediction of outcome in pediatric acute lymphoblastic leukemia by gene expression profiling. Cancer Cell. 2002; 1:133-43. [PubMed: 12086872]

105. Li L, Li M, Sun C-L, et al. Altered Hematopoietic Cell Gene Expression Precedes Development of Therapy-Related Myelodysplasia / Acute Myeloid Leukemia and Identifies Patients at Risk. Cancer Cell. 2011; 20:591-605. [PubMed: 22094254]

106. Krishnan A, Bhatia S, Slovak ML, et al. Predictors of therapy-related leukemia and myelodysplasia following autologous transplantation for lymphoma: an assessment of risk factors. Blood. 2000; 95:1588-93. [PubMed: 10688812]

107. Milligan DW, Ruiz De Elvira MC, Kolb HJ, et al. Secondary leukaemia and myelodysplasia after autografting for lymphoma: results from the EBMT. EBMT Lymphoma and Late Effects Working Parties. European Group for Blood and Marrow Transplantation. Br J Haematol. 1999; 106:1020-6. [PubMed: 10520006]

108. Koontz MZ, Horning SJ, Balise R, et al. Risk of therapy-related secondary leukemia in Hodgkin lymphoma: The Stanford University experience over three generations of clinical trials. J Clin Oncol. 2013; 31:592-8. [PubMed: 23295809] 
Table 1

Magnitude of Risk and Populations at Increased Risk of Therapy-related Leukemia

\begin{tabular}{|c|c|c|c|c|}
\hline Study & Study design & $\begin{array}{l}\text { Sample size/ } \\
\text { number of } \\
\text { SMNs }\end{array}$ & $\begin{array}{l}\text { Primary Diagnoses } \\
\text { Type of HCT }\end{array}$ & $\begin{array}{l}\text { Magnitude of Risk and } \\
\text { Risk Factors }\end{array}$ \\
\hline \multicolumn{5}{|c|}{ t-MDS/AML after autologous Hematopoeitic cell Transplantation } \\
\hline $\begin{array}{l}\text { Krishnan A et al. } \\
\text { Blood. 2000;95:1588- } \\
\text { 1593106 }\end{array}$ & $\begin{array}{l}\text { Retrospective } \\
\text { cohort study } \\
\text { Nested case- } \\
\text { control study }\end{array}$ & $\begin{array}{l}612 / 22 \\
\text { MDS/AML }\end{array}$ & $\begin{array}{l}\text { Hodgkin lymphoma } \\
\text { Non-Hodgkin lymphoma } \\
\text { Autologous HCT }\end{array}$ & $\begin{array}{l}\text { Cumulative probability of } \\
\text { MDS/AM L }: 8.6 \% \text { at } 6 \\
\text { years } \\
\text { Stem cell priming with VP- } \\
\text { 16, pre-HCT radiation } \\
\text { associated with increased } \\
\text { risk of t-MDS/AML }\end{array}$ \\
\hline $\begin{array}{l}\text { Milligan DW et al. Br } \\
\text { J Haematol. } \\
\text { 1999;106:1020- } \\
1026^{107}\end{array}$ & $\begin{array}{l}\text { Retrospective } \\
\text { cohort design }\end{array}$ & $\begin{array}{l}4,998 / 66 \\
\text { MDS/AML }\end{array}$ & $\begin{array}{l}\text { Hodgkin lymphoma } \\
\text { Non-Hodgkin lymphoma } \\
\text { Autologous HCT }\end{array}$ & $\begin{array}{l}\text { 5-year cumulative } \\
\text { probability was } 4.6 \% \text { for HL } \\
\text { and 3\% for NHL. } \\
\text { Older age at HCT, diagnosis } \\
\text { of HL, exposure to TBI, } \\
\text { multiple HCT, years } \\
\text { between diagnosis were } \\
\text { associated with increased } \\
\text { risk of MDS/AML }\end{array}$ \\
\hline $\begin{array}{l}\text { Bhatia S, et al. Blood } \\
\text { 1996;87:3633-910 }\end{array}$ & $\begin{array}{l}\text { Retrospective } \\
\text { cohort design }\end{array}$ & $\begin{array}{l}\text { 258/10 } \\
\text { MDS/AML }\end{array}$ & $\begin{array}{l}\text { Hematologic malignancies } \\
\text { Autologous HCT }\end{array}$ & $\begin{array}{l}\text { 6-year cumulative } \\
\text { probability was } 13.5 \% \text {. } \\
\text { Peripheral blood stem cell } \\
\text { transplantation } \\
\text { Age }>35 \text { years at autologous } \\
\text { hematopoietic cell } \\
\text { transplantation }\end{array}$ \\
\hline $\begin{array}{l}\text { Friedberg JW, et al. J } \\
\text { Clin Oncol } \\
1999 ; 17 ; 3128-35^{92}\end{array}$ & $\begin{array}{l}\text { Retrospective } \\
\text { cohort design }\end{array}$ & $552 / 41$ & Non-Hodgkin lymphoma & $\begin{array}{l}\text { Fewer number of cells } \\
\text { infused }\end{array}$ \\
\hline \multicolumn{5}{|c|}{ t-MDS/AML after conventional therapy } \\
\hline $\begin{array}{l}\text { Koontz MZ et al. J } \\
\text { Clin Oncol } \\
\text { 2013;31:592-8 } 108\end{array}$ & $\begin{array}{l}\text { Retrospective } \\
\text { cohort design }\end{array}$ & $754 / 24$ & Hodgkin lymphoma & $\begin{array}{l}\text { 10-year cumulative } \\
\text { incidence ranged from } 0.3 \% \\
\text { to } 5.7 \% \text {. } \\
\text { Cumulative alkylating agent } \\
\text { exposure increased the risk }\end{array}$ \\
\hline $\begin{array}{l}\text { Bhatia S et al. N Engl } \\
\text { J Med 1996;334:745- } \\
51^{3}\end{array}$ & $\begin{array}{l}\text { Retrospective } \\
\text { Cohort design }\end{array}$ & $1380 / 26$ & Hodgkin lymphoma & $\begin{array}{l}\text { 14-year cumulative } \\
\text { probability was } 2.8 \% \\
\text { Treatment with alkylating } \\
\text { agents, age at diagnosis at } 10 \\
\text { to } 16 \text { years (c/w < } 10 \text { years), } \\
\text { recurrence of primary } \\
\text { disease risk, and a late stage } \\
\text { of disease at diagnosis were } \\
\text { associated with an increased }\end{array}$ \\
\hline $\begin{array}{l}\text { Bhatia S, et al. Blood } \\
\text { 2002;99:4257-647 }\end{array}$ & $\begin{array}{l}\text { Retrospective } \\
\text { cohort design }\end{array}$ & $8831 / 14$ & $\begin{array}{l}\text { Acute lymphoblastic } \\
\text { leukemia }\end{array}$ & $\begin{array}{l}15 \text {-years cumulative } \\
\text { incidence was } 0.3 \% \text {; relapse } \\
\text { of primary disease was } \\
\text { associated with increased } \\
\text { risk }\end{array}$ \\
\hline $\begin{array}{l}\text { Bhatia S et al. Blood } \\
2007 ; 109: 46-51^{6}\end{array}$ & $\begin{array}{l}\text { Retrospective } \\
\text { cohort study } \\
\text { design }\end{array}$ & $578 / 11$ & Ewing sarcoma & $\begin{array}{l}\text { 5-year cumulative incidence } \\
\text { of } 2 \% \text {; increasing exposure } \\
\text { from } 90 \mathrm{~g} / \mathrm{m} 2 \text { to } 140 \mathrm{~g} / \mathrm{m} 2 ; \\
\text { cyclophosphamide from } 9.6 \\
\text { to } 17.6 \mathrm{~g} / \mathrm{m} 2 \text { and } \\
\text { doxorubicin from } 375 \text { to } 450 \\
\mathrm{mg} / \mathrm{m} 2 \text { increased the risk }\end{array}$ \\
\hline $\begin{array}{l}\text { Travis LB et al. N } \\
\text { Engl J Med. } \\
\text { 1999;340:351-79 }\end{array}$ & $\begin{array}{l}\text { Case-control } \\
\text { study design }\end{array}$ & $\begin{array}{l}\text { Cases: } 96 / \\
\text { controls: } 272\end{array}$ & Ovarian cancer & $\begin{array}{l}\text { Relative risk for treatment } \\
\text { with carboplatin and } \\
\text { cisplatin increased the risk in } \\
\text { a dose-dependent fashion }\end{array}$ \\
\hline
\end{tabular}




\begin{tabular}{|l|l|l|l|l|}
\hline Study & Study design & $\begin{array}{l}\text { Sample size/ } \\
\text { number of } \\
\text { SMNs }\end{array}$ & $\begin{array}{l}\text { Primary Diagnoses } \\
\text { Type of HCT }\end{array}$ & $\begin{array}{l}\text { Magnitude of Risk and } \\
\text { Risk Factors }\end{array}$ \\
\hline $\begin{array}{l}\text { Travis LB et al. J Natl } \\
\text { Cancer Inst } \\
\text { 2000;92:1165-718 }\end{array}$ & $\begin{array}{l}\text { Case-control } \\
\text { study design }\end{array}$ & $\begin{array}{l}\text { Cases: } 36 ; \\
\text { controls: } 106\end{array}$ & Testicular cancer & $\begin{array}{l}\text { Radiation to active bone } \\
\text { marrow (dose-dependent } \\
\text { relation); cumulative dose of } \\
\text { cisplatin }\end{array}$ \\
\hline
\end{tabular}

